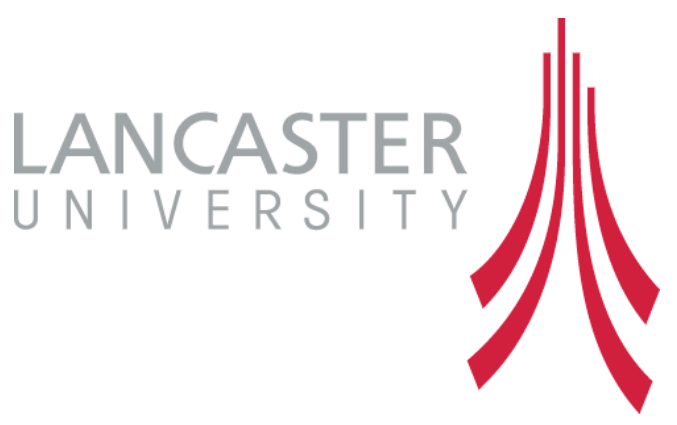

\title{
Materiality and Civilization: Things and
}

\section{Society}

The final version of this paper was published in Italian in British Journal of Sociology, Vol. 57 (2): 289-308. Please quote and cite the published version.

\section{Tim Dant}

Department of Sociology

Bowland North

Lancaster University

Lancaster, LA1 4YT

t.dant@lancaster.ac.uk

01524593184 


\section{Material Civilization: things and society}

\section{Abstract}

This paper argues that although classical sociology has largely overlooked the importance of social relations with the material world in shaping the form of society, Braudel's concept of 'material civilization' is a useful way to begin to understand the sociological significance of this relationship. The limitations of Braudel's historical and general concept can be partially overcome with Elias's analysis of the connection between 'technization' and 'civilization' that allows for both a civilizing and a de-civilizing impact of emergent forms of material relation that both lengthen and shorten the chains of interdependence between the members of a society. It is suggested that the concept of the 'morality of things' employed by a number of commentators is useful in summarising the civilizing effects of material objects and addressing their sociological significance. From the sociology of consumption the idea of materiality as a sign of social relationships can be drawn, and from the sociology of technology the idea of socio-technical systems and actornetworks can contribute to the understanding of material civilization. It is argued that the concept of 'material capital' can usefully summarize the variable social value of objects but to understand the complexity of material civilization as it unfolds in everyday life, an analysis of 'material interaction' is needed. Finally the paper suggests some initial themes and issues apparent in contemporary society that the sociological study of material civilization might address; the increased volume, functional complexity and material specificity of objects and the increased social complexity, autonomy and substitutability that is entailed. A theory of 'material civilization' is the first step in establishing a sociology of objects.

Keywords: Materiality; civilizing process; water; material capital; material interaction 


\section{Introduction}

It is probably not quite the case that the sociology of objects is a field of enquiry yet. But there are a number of areas of sociology, and the social sciences more broadly, that indicate the beginnings for such a field of enquiry. The argument of this paper is that Braudel's provocative phrase 'material civilization' provides a useful conceptual device for bringing together a sociological approach to objects from discussions in history, anthropology, social studies of technology and the sociology of consumption. There is not the space in a short paper to do any sort of justice to the range and complexity of these various explorations of social relationships with material objects so I will no doubt anger those who will insist that such-and-such a field, or so-and-so's work already does what I am proposing here. ${ }^{1}$ If I do provoke such anger, so much the better: what is perhaps lacking is a debate at the general level of sociology about the significance of material objects in contributing to culture and society in late modernity.

The argument can be simply put. The social and cultural relations between individuals in late modern societies would seem to be, more than at any time in the past, mediated via material objects. This is not to say that intermediated relations have displaced face-to-face relations - although the electronic technologies of telephony, computing and broadcasting all insert themselves in many of our human to human interchanges. Nor is it to go as far as that arch technological determinist Marshall McLuhan's buzz phrase, 'the medium is the message' (1994). ${ }^{2}$ Instead of arguing that the technologies are taking over or that they are determining social life, I want to point to the increasing presence and importance of our material life in constituting what society and culture is. The reason for this historical effect is of course tied up with technology. Human animals, like all other animals, have always inhabited a material environment, one that we often refer to with the catch all term 'nature'. And what has often been treated as distinguishing human animals from other species is their capacity to take and shape parts of that nature to adapt it to their 
requirements. ${ }^{3}$ But what technology has led to is a rapidly changing material environment experienced by many humans, especially those in the densely inhabited parts of the industrialized world, that has been made by other humans. The pace of change in this material environment and the numbers of people who are involved with it is greater than at any time in the past.

What I will do is to argue firstly that while classical sociological theorists - with some notable exceptions - have largely overlooked the role of materiality in modern social formations, Braudel offers an historical argument about material civilization. To make this argument more properly sociological, I will use Elias's conception of the civilizing process and his discussion of technization. To begin to think about how to study material civilization in late modernity, I will draw on some other perspectives, including those associated with consumption and technology. Finally, I will discuss some of the features of materiality in late modernity that might be indicative of the trajectory of its material civilization.

\section{Modernity and materiality}

The classical sociologists analysed the transformation from traditional to modern societies with accounts of work, religion, money, mores, culture and social class but they had little to say about material civilization. Marx's analysis of the economic changes of capitalism led to themes such as the division of labour, class relations and the reorganisation of work that were developed by the other classical sociologists, often distinguishing the social from the economic. Durkheim (1933) focuses on 'social solidarity' and the 'conscience collective', Weber's analysis (1978) is directed to themes of power, religion, social action and rationality and Simmel's sociology (1950) is concerned with social 'forms', modes of 'sociation' and the significance of money (1971). ${ }^{4}$ These quintessentially 'immaterial' aspects of society, that concerned sociology throughout the twentieth century, do not recognize the significance of material civilization in the historical transformation of society. 
Of course the major exception is Marx himself who identifies the importance of 'practical, human-sensuous activity' (Marx 1975: 422) in his early philosophical writing on materialism. Together with Engels (1971), his later writing documents the impact of mechanized manufacturing on the material lives of workers as technology was utilized to transform raw materials into goods for human use. ${ }^{5}$ Marx understood the impact of machines on the labour process and the economics of the productive process (Marx 1973: 692-5) but he also showed how introducing machines, especially self-acting machines, transformed the material lives of humans as agents in the manufacturing process (Marx 1976: 455-639). Veblen too analysed the impact of machinery on work and 'workmanship' (1964) that led to the emergence of a set of social relationships based on increasingly abstract and impersonal modes of action as embodied work became mechanized. These classical authors describe the transformation in material civilization that came with modernity from the perspective of industrial production but remark on the change in material life in general only fleetingly. Marx does mention that the increase in productivity stimulated demand both for consumer goods and for a developed public material environment that included canals, docks, bridges, tunnels, gas-works, telegraphy, photography, steam navigation and railways (Marx 1976: 573). However, the passing remarks that he makes on the importance of consumption in mediating production (e.g. Marx 1973: 90-4) are brief and amount to little beside his major work. ${ }^{6}$ Veblen (1925) is famous for setting out the impact of pecuniary culture as leading to social distinction and the desire to emulate through conspicuous consumption, but he does not address the impact of artefacts on social and cultural life beyond that of the leisure classes.

Writing in 1979 Fernand Braudel (1992) took a rather different view from the classical sociologists of the economic developments that led to modern societies. The traditional view from history focused on economic institutions, including the state, banks and new developments such as the joint stock company, to describe the 'gradual progress towards the rational world of the market, the firm and capitalist investment' (Braudel 1992: 23). In 
contrast, Braudel drew attention to the more basic aspects of the lives of everyone in a society, not just the capitalist and the labourer but also those outside the formal process of economic production. Economics, he argued, is about the practical, everyday business of meeting needs, which includes production and consumption, but also includes material life beyond the sight of economic institutions. This zone of material life lies beneath the zone of the market economy which in turn lies beneath that zone of economic activity where a few favoured key players influence the market: 'This rich zone, like a layer covering the earth, I have called for want of a better expression material life or material civilization' (Braudel 1992: 23 - emphasis in the original). Braudel does not suggest that any one layer is historically determinative but argues that we cannot understand economic history by simply studying the evolution of the market and its institutions or by studying the key players. It is his interest in this lowest zone of material life that goes beyond the production-oriented analyses of Marx and Veblen and even the culture of consumption described by Veblen.

In the first of his three volumes Braudel describes material life in its geographical and historical complexity through a series of themes - demography, food, costume, lodging, technology, money and towns (1992: 27). It is in these dimensions of material life that economic history can be seen to shape what it is to be a member of human society. Between the fifteenth and eighteenth centuries, change in these material aspects of social life was slow but in the nineteenth century a rapid period of transformation overcame this inertia to produce the material civilization that we associate with modernity. Braudel's history is of the material civilization of the centuries leading up to the industrial revolution: it varied across the world but often not to a great extent. He describes how ordinary life was for most people and, unlike Veblen and Sombart, does not emphasize the material life of the wealthy. There were local ways of doing things and innovations in material life were local rather global - this was because change always responded to the complexity of material life as it was lived and the impact of innovation in one aspect of life would affect innovation in another. 
In keeping with the Annales tradition passed on from Febvre and Bloch (Burke 1990), Braudel's history explores the changes in different cultures as the long durée of an epoch plays out. A useful illustrative example is water - water is a component in material civilization that has many ramifications for different aspects of social life and affects demography, food, the development of towns and becomes entwined with money. Many early settlements were established close to a supply of water not only for drinking but also for cleaning and washing and the removal of waste. Where the water source was a substantial river, its flow could meet these needs as well as providing a thoroughfare for trade and a crossing point and conjunction for overland routes. The material culture of direct water use develops its own technology that is primarily about getting it to people for drinking and washing. There were fountains, aqueducts and cisterns before the industrial revolution but they were few and far between and technically very limited. Most drinking water was gathered and moved around cities by hand in buckets and in Paris, for example, water from the Seine was delivered by twenty thousand carriers who earned their living doing it. The river water was polluted of course - not least by dyers - and the Seine was also used for bathing, such as it was, and its banks were an open lavatory (Braudel 1992: 228-31). Steam pumps began to appear towards the end of the eighteenth century and during the nineteenth century a rapid series of developments separated polluted and fresh water. Daniel Roche (2000) picks up the theme, explaining how water is tied into just about every aspect of everyday material life. Water is not only for drinking but also for making bread, wine and many forms of food - the wells in Paris used by the bakers were contaminated with 'infiltrations' that according to Braudel made it taste even worse than the river water (Braudel 1992: 229; see also Roche 2000: 148). Water for washing bodies and clothes is linked to health and the quality of communal life (Roche reckons there were 2,000 places for washer women along the Seine during the seventeenth and eighteenth centuries - 2000: 161). But water also has a symbolic quality in religious ceremonies, most particularly baptism, as well as providing 'an element of décor' 
for the rich who would use it for watering gardens and for decorative fountains (Roche 2000: 156).

As we read these historians of everyday material life we are struck by how different life was just a couple of hundred years ago. Other historians may offer a very different analysis of the pace and causes of change than Braudel but none the less point to a similar shift in the material civilization surrounding water. An historian with a very different approach, Jean-Pierre Gourbet, sees the massive changes brought about by the industrialization of water as proceeding "extremely slowly" over what for Braudel would be a historically very short period between 1880 and 1940 (Gourbet 1986: 23). Braudel says that while the ideas of Voltaire's age would not be so different than the ideas of our own, his material life would contrast dramatically with ours (Braudel 1992: 27-28). But Gourbet points out the impact of ideas and knowledge about water; its chemical composition, its impact on hygiene and the technology by which to move it. He also shows how these ideas interacted with the cultural acceptance of water into everyday life. ${ }^{7}$ However, after a long period of little change, the coming of industrialization dramatically changed material civilization and modernity has seen a continuing rapid transformation in material life since the end of the eighteenth century when Braudel and Roche finish their histories of everyday life. In late modernity, we in the West have come to take water for granted; we wash our bodies, our clothes, and flush our lavatories using water from the same source that we drink from, treating it as 'natural', confident that it will not immediately affect our health. ${ }^{8}$ We buy electric fountains for the garden, paddling pools for the children, automatic watering and sprinkling systems for flowerbeds and greenhouses along with hoses and high pressure jets for cleaning everything from the car to the stonework on the patio. In the house we can have automatic washing machines, dishwashers, power showers, baths, multiple sinks and toilets and a central heating system based on hot water circulated in radiators. Each of these uses draws water 'on tap' from an apparently inexhaustible mains supply. What was once a social, public process in which everyone's private needs were displayed has become a private, virtually 
invisible process in which 'need' is shaped by cultural influences (Shove 2003). Roche describes how just a couple of centuries ago the smell of an unwashed body indicated prosperity and says '... the French, associating strong smell with good health, kept up a long-lasting collective distrust regarding all ablutions' (2000: 158). Today cultural values and I include the French here - have reversed so that the unwashed body stands out offensively in the crowd of frequently washed and fragrant bodies. In other parts of the world, water is in shorter supply and yet is often used for agriculture or in industrial processes that meet the material needs of richer countries.

In the West we no longer pay for our water with the bodily labour of transporting it, a payment that gives a keen opportunity cost to each last cupful, but pay on account with money for its provision at our behest. As the technology of damming rivers, building reservoirs and pumping it long distances has improved, it has transformed the value of water and increased the uses we find for it. We expect to have as much as we want and become indignant when our local supply becomes contaminated or interrupted. Unwanted water itself can however destroy the material life surrounding water use. After the tsunami in the Indian Ocean on December $26^{\text {th }} 2004$, the drinking water supply for millions of people was compromised as the inrush of seawater destroyed the distinction between soiled and fresh water. In the wake of the tsunami drinking water was distributed in sealed plastic bags, then a couple of weeks later quite unconnected floods in Hexam in the UK cut off water supplies to 7000 homes and led to water being given out from bowsers and in plastic bottles. ${ }^{9}$ In both the industrialized and the developing world the repair of the fresh water supply was an urgent technical issue involving plant, chemical treatments, engineers and advice to boil water until safe supplies were reinstated. Inundation with the wrong sort of water requires an urgent socio-technical response to sustain the material life of a modern society. 


\section{The civilizing process and technization}

It is remarkable that the process of material civilization - which has carried on at a stunning pace throughout the twentieth century and of which water is only a small aspect has largely been overlooked by sociology. Braudel himself does not try to analyse the social impact of material civilization, he takes his task as merely to note the changes in everyday material life that occurred during the pre-modern period. However, Norbert Elias's magisterial work, The Civilizing Process (1994), which in common with the Annales approach takes a very long view of history and attends to some of the ordinary features of everyday life, develops a sociological account of civilization as a process. Elias is particularly concerned with court society and the social dynamics of its etiquette that exemplify a change in individual behaviour that allows ever larger social formations, resulting in the nation-states of modernity. Rather than the fundamentally economic relations that concerned Braudel, Elias's focus is on the social relations surrounding the actions of individuals that intrude into the sensibility of others. For him, civilization is a process characterized by a lengthening of the chains of interdependence of individual actions that occurs as people have more contact with more different people whom they know little or not at all but who share the same society. This occurs, as the classical sociologists recognized, with an increasing division of social functions and as societies increase in size but for Elias civilization is an historical process that involves both the gradual change of social structures and a parallel change in the mode of interpersonal relations:

As more and more people must attune their conduct to that of others, the web of actions must be organized more and more strictly and accurately, if each individual action is to fulfil its social function. The individual is compelled to regulate his conduct in an increasingly differentiated, more even and more stable manner.

(Elias 1994: 445)

At first glance this civilizing process has little to do with materiality and appears to be principally to do with patterns of behaviour; the restraint from the use of violence, the 
extension through society of civility and good manners, the development of shame and repugnance. But Elias's argument passes through many elements of materiality, often to do with the management of the body. So, washing one's hands in water prior to eating becomes one of the features of courtly manners and the privatization of bathing - at first covering the body on the way to the communal bathing, later bathing in privacy - are features of the change in the restraints on behaviour (Elias 1994: 49-52). The introduction of handkerchiefs, napkins, individual cutlery, crockery and beds are all part of the emerging process of separating individual bodily functions and finding ways to minimize the disgust caused to others. As he comments, the importance of waterways and seaports as centres of trade networks and therefore of population, coincides with a lengthening of chains of social action that required increasing foresight and increasing self-control and affect-inhibition (Elias 1994: 457). But it is Elias's use of the development of roadways and traffic as a metaphor to explain the civilizing process that most readily evokes the interconnection of materiality and civilization. He contrasts the simple road system of the warrior society that exchanges through barter, with the complex road system of modern, money-based economies. The road user in the former society is confronted by a few crude, uneven, unmetalled roads that are exposed to damage by wind and rain and where the greatest danger is from attack by soldiers or thieves. But the road user in the modern society has a different mindset because the traffic is thick and fast moving on a complex road system and the greatest danger results from someone losing their self-control: 'If the strain of such constant self-control becomes too much for an individual, this is enough to put himself and others in mortal danger' (Elias 1994: 446)

These remarks on the road system were an aside but Elias returned to the theme in a paper that specifically addressed the relationship between the civilizing process and technization (1995). In an uncharacteristic exploration of the statistics of road deaths, he shows that the technization of society that occurred with the adoption of the private motorcar, despite its civilizing effects, also produced the unintended de-civilizing effect of 
causing death and injury (Elias 1995: 21). Technization is that process by which "people learn to exploit lifeless materials to an increasingly greater extent for the use of mankind' (Elias 1995: 7) and its motivation is the goal of a 'better life'. ${ }^{10}$ But because each is interwoven with the other, neither civilization nor technization is the leading process or the cause of the other. Both are dependent on the human ability to postpone gratification through self-regulation in the hope of a future increase or stability in gratification - however, at times one of these processes seems to be more dynamic and to create unintended effects in the other. Mobility provides gratification for humans either through the experiences it opens up or through the sheer pleasure in effortless movement and speed it provides. The revolutionizing of transport throughout the nineteenth and twentieth centuries seems to have been progressive; increasing power (speed, distance), increasing independence from natural processes (such as animal or wind power), increasing control, and operability in increasingly alien media (land, water, air, space).${ }^{11}$ Elias points out that this trajectory of development can be seen as a coherent process only in retrospect because it was in fact unplanned, resulting as it did from 'the effects of the interweaving of many individual activities reinforcing and counteracting each other' (1995: 13).

The dangerous and de-civilizing effects of the technization of the motor car were recognized early on and subject to regulation - Elias reminds us of the laws in nineteenth century England about men with red flags walking in front and maximum speeds that progressively changed from 4 to, 10 to 20 miles per hour. But a civilizing process that 'demanded high discipline among the participants, a uniform and moderate self-regulation', also accompanied the same trajectory of technization and Elias argues that it is the selfregulation of drivers which is of the greatest significance in counteracting the de-civilizing effect of cars (1995: 18). He recognizes that improvements in the technology of the motor car and of the engineering of roads made motor-cars not only faster but also safer. Moreover, social regulations about seat belts and alcohol consumption, speed limits, police activity and traffic engineering have all helped to provide a 'social standard' for self- 
regulation. Standardized rules become an internalized habit for drivers so that what might appear to be an abstract legal or political process is in fact both expressive of and indicative of a civilizing process; ' $\ldots$ individual self-regulation of the driver, the regulation of his or her own behaviour in relation to other people, remains undirected and dangerous if it is not oriented towards socially standard regulations which all drivers share' (Elias 1995: 25). Elias emphasizes civilization as impacting on individuals who internalize standards of behaviour he discusses the social response to de-civilizing effects primarily in terms of laws and regulations. A rather different approach would emphasize the shift in moral culture that is the product of a range of socialization processes - driver training, media advertisements, public discussion and speed control strategies for example. As drivers respond to the mechanisms of socialization within their culture, they develop an embodied relationship with their vehicles that involves far more than just accepting standards of behaviour (Dant 2004). Elias ignores both the moral culture of socialization and the moral effect of material civilization that becomes embedded in material technologies to constrain and direct individual action on the roads - things like local transport planning, road design, vehicle design, speed cameras and speed bumps. Civilization is not only internal as behaviour but is also external as socialization and even takes material forms.

A recent literature has begun to address the 'morality of things', (e.g. Costall 1995: 473; Molotch 2003: 225-59) and the extent to which people or objects can be treated as responsible for a line of action is often raised in relation to the possession of guns (Csikszentmihalyi and Rochberg-Halton 1981: 16; Hutchby 2001: 446; Gell 1998: 20-1; Latour 1999: 179). Bruno Latour has returned to the theme of the morality of things a number of times in relation to the effects of door closers $(1988,1992)$, seat belts (Latour 1992) and speed bumps (Latour 1992, 1999) - artefacts that are designed to constrain or shape the actions of individuals on behalf of society as a whole. The civilizing effect of technization that promotes self-regulation is demonstrated where the driver learns to slow down for speed bumps because the de-civilizing effect of their speed, and so the danger to 
other road users, is converted into their discomfort and potential damage to their car. This dynamic of material civilization suggests that we should be cautious of Elias's argument (1995: 13) that the trajectory of civilization is an unplanned process - clearly those who exercise power on behalf of a community do plan the design and introduction of such devices as speed bumps and cameras. The cultural response that attempts to reduce the violent consequences for others within the society of individual desires, involves a lengthening of the chains of interdependence between people. This happens not only through self-regulation because constraints remain external as legal sanctions (the speeding fine) and material forms (the speed bump).

\section{Studying materiality and society}

If the classical sociologists had little to say about consumption as a socio-economic process, it became a lively area for social analysts in a number of disciplines in the latter half of the twentieth century (in the UK for example: Douglas and Isherwood 1979; Campbell 1989; Miller 1987; McKendrick, Brewer and Plumb 1983; Slater 1997). Much of the focus was on the cultural practices that surround consumption and the way that these connect the individual to the society in which he or she lives. To put the matter grossly, what is consumed cannot simply be treated as functional to the animal life of the human but is a cultural process that indicates the social status and individual identity of the consumer. The consumption of material objects is part of this process so that the elements of material life can be treated as having meaning. For Jean Baudrillard, whether he is writing about stucco, adornment or cloning, material life is taken to be representative of something social that is beyond the embodied experience of the individual (Baudrillard 1993; 2000). For Pierre Bourdieu social distinction between class fractions is indicated by the effect of taste on consumption (1984). The everyday life theorists, notably de Certeau (1984; Certeau, Giard and Mayol 1998) and Lefebvre (1971), also showed how material life could be transformed through consumption practices around food, clothing and domestic life but the focus was on 
the political impact of these practices. However, the predominant focus in the consumption literature is on cultural meaning and social status rather than on the process of material civilization.

A parallel and equally multi-disciplinary literature to that of consumption emerged in the 1980 s to address the social dimensions of technological development (see for example the edited collections by MacKenzie and Wajcman 1985; Callon, Law and Rip 1986; Bijker, Hughes and Pinch 1987; Bijker and Law 1992). In contrast to a traditional approach that had traced the social contingencies of technological advances, the social construction of technology thesis, argued 'not only that there is flexibility in how people think of or interpret artefacts but also that there is flexibility in how artefacts are designed' (Pinch and Bijker 1987: 40). This body of theory and research shifted how technological innovation was understood; as against any technological determinism in which discrete artefacts emerged from technologists' research laboratories to change our worlds, here was an argument that civilization shaped technization just as much as the other way around. Instead of technical systems being seen as relatively autonomous, following Hughes (1983) pioneering work, they became understood as interconnected socio-technical systems and later as 'actornetworks' in which material objects - nonhumans - had a measure of agency alongside that of the human actors (Callon 1986; Latour 1988; Law and Callon 1992).

The social studies of consumption and of technology have extended particular aspects of our understanding of the process of material civilization. The study of consumption has shown that material objects have meanings that are implicated in our social arrangements, specifically in distinguishing and maintaining social structure. Materiality is tied up with our everyday concerns, the procession of activities that sustain individual life but also sustain social life. The study of technology has shown that material objects are not 'discovered' like unexplored islands, but that they are 'constructed' through sets of social processes that include the capacities of objects themselves. While artificial material objects are literally 'inanimate' (despite a continuing human fascination with making 
objects that mimic life), they are imbued and embedded with the social; meanings are attributed and built in, capacities and extensions of human action are incorporated within them. The objects created by a civilization both constitute and reflect the nature of that civilization.

A way of summarizing these social properties of material objects is to extend the economists' concept of 'fixed capital' to think of all recognized 'things' as constituting 'material capital'. ${ }^{12}$ The value in material objects that are incorporated into social life does not derive exclusively from their origins in production, from their meanings in consumption, from their practical use in everyday life or from the networks associated with their emergence as technical entities - it derives from all of these. The value of material objects is not stable in relation to the biological needs of humans but is socially variable and changes with the process of material civilization - how we value water, for example, depends on how easily accessible it is. The notion of 'material capital' allows for objects to accrue value that is invested by the culture and released by individual use, it can take the form of aesthetic qualities, functionality or enhancement of bodily capacity. My car, for example, has a material capital that is invested in the object through the skill and effort of designers, engineers, manufacturers and marketers to create a bundle of uses; mobility, comfort, social status, pleasure, carrying capacity. These uses are realised through my everyday engagement with the object that can last as long as the material capital has a value. The material capital of my car 'wears out' not simply through the car's engineering wearing out but through its style becoming unfashionable or its comfort or capacity inappropriate to my changing lifestyle or body. Material capital is of course also invested in objects that are collectively owned and used, whether in private or public ownership. Buses and trains, swimming pools and water companies are all subject not only to the decline in their material properties as they wear out, but in their technical and aesthetic capacity as material civilization proceeds. The acquisition of material capital involves storing in material objects signs, functions and capacities that can be shared between people, retained for future use, 
passed on from one to another and, of course, can ultimately be exchanged for economic capital. What counts as material capital changes with the process of material civilization and is not necessarily transferable between stages in civilization. The fashionable frock from one era may be discarded as worthless tat or become the much desired antique of another, the functional workers cottage of one era may collapse or become the highly valued retirement property of another era.

\section{Material interaction}

One of the reasons for emphasizing the relationship between materiality and civilization is to shift the attention from the abstract to the material level of existence; it is not ideas as such that are indicative of a civilization, it is how those ideas are manifest at the material level that is important. The materiality of a culture impacts on the materiality of people and it is their embodiment that is at issue; the embedded material capital of objects is realized through its relationship with bodies. Water quenches thirst and washes bodies, but can wash away people and homes, cars give people mobility but can cause damage, injury and death to their bodies. There is a risk of 'oversocializing' materiality by treating meanings and statuses, networks and agency, as having greater importance than their material effects on people - but whatever else material civilization is, it is always embodied. While we may sometimes feel that we experience existence through the mind and imagination, the body is always the vehicle of this experience and our engagement with other people and other objects is always mediated through the body. To understand the process of material civilization requires an analysis of material interaction, that is, the concrete relationships between people and things. Material interaction is the meeting of the materiality of peoples' bodies, including the mind and imagination that are part of those bodies, with the materiality of objects, including the qualities and capacities that have been designed and built in by the combined and collective actions of a series of other people. 
A strand of anthropological thinking that has begun to address the social impact of interaction between bodies and the material world finds a key source in Mauss's (1973) discussion of 'techniques of the body', first published in 1934. He argued that how people used their bodies was not simply 'natural', or animalistic, but was in some senses 'cultural'; French soldiers digging trenches during the first world war could not use English spades and vice-versa so that the spades had to be changed when the troops were. For Mauss it was the cultural specificity of the bodily technique of digging that was important but Parlebas (1999) extends this to include the world of material objects - such as sports equipment as well as tools - that are embedded in a culture that shapes material interaction in ways that are not easy to recognize from within the situation. Warnier's (2001) concept of 'praxeology' brings together the emotional, symbolic and motor aspects that constitute the culture of material interaction between bodies and objects.

It is however Maurice Merleau-Ponty's (1962) phenomenological analysis of being-inthe-world as fundamentally embodied, that situates human being in a materially constituted world engaged through the conscious body and its sensations. The minded body is at the centre of the experience of material civilization and is the medium through which the everyday is lived: 'In short, my body is not only an object among all other objects, a nexus of sensible qualities among others, but an object which is sensitive to all the rest, which reverberates to all sounds, vibrates to all colours, and provides words with their primordial significance through the way in which it receives them' (Merleau-Ponty 1962: 236). ${ }^{13}$ Merleau-Ponty does not privilege mind over body but rather sees these two aspects combined in a series of relationships between the inside and the outside of bodies, especially perception and intentionality, that are, at least in part, moulded by culture and experience. By developing an approach to the material interaction between bodies in a social context and the material stuff that society makes available to them, we can begin to understand some of the detail of the process of material civilization (see for example Hindmarsh and Heath 2003; Dant 2005: 84-135). 


\section{Material civilization in late modernity}

If Braudel describes the material civilization leading up to modernity and Elias's concept of technization shows how it accelerates within modernity, then how can we understand it in late modernity? A way of summarizing material civilization in late modernity is to point to the increasing rapidity, complexity and range of technological development. The impact of collective human action does not simply risk local pollution of a social group's own water supply, it can affect the availability and usage of water for those many hundreds of miles away and for those who have yet to be born. Dams on rivers and the redirection of water can have immense consequences, many unintended or unimagined, that have a socially transforming impact for large populations (Heidegger 1977: 14; Ellul 1965: 323). The critics of technology have pointed to the social impact of such large-scale technologies but there has been less comment on more widespread but smaller changes in material civilization whose impact is cumulative rather than sudden. There are gross changes in the process of material civilization of late modernity that can be highlighted:

1) Volume: There are simply more human-produced things in the world, especially filling the lives of those in the rich, western, industrialized countries. In the flow of our everyday lives we interact with a greater range of different types of objects; where once there was just the pen and paper, now there is the computer keyboard and the personal organizer as well.

2) Functional complexity: Electrical, electronic and now digital capacity increasingly allows the material objects that fill our lives to fulfil an increasing range of functions. The self-acting industrial machine Marx described now inhabits our everyday lives the difference is that we at least feel that we have control over the use and purpose of these objects. 
3) Material specificity: The plastics, ceramics, metals and other materials of which the goods that surround us are made, are designed for particular uses. The result is that the material that they are made from is less likely to determine the form of objects and their lifespan so that machines and other used objects become obsolete - through fashion or superseded functionality - long before they are broken or worn out.

It is likely that future historians will identify relatively small items that we take for granted, as having the most significant civilizing effects (the credit card, the contraceptive pill), but their impact is difficult to gauge close to. However, the increasing volume, complexity and material specificity of the material world of those of us living in western, industrialized countries can already be recognized as having far reaching civilizing effects as the chains of interdependence between people are lengthened by the materiality of social life. These effects may not be equally distributed throughout the social spectrum but their effect is far from restricted to a privileged elite:

Firstly, they lengthen the chains of interdependence as the objects we encounter connect us with more people. Objects, such as the car, mobile phone and computer that extend our communicative ability obviously increase the numbers and types of people with whom we have contact. Other objects that do not so obviously connect with others, such as the washing machine, link us to those who design, manufacture and sell it and they connect us to patterns of behaviour that are characteristic such as the frequency with which we wash our clothes (Shove 2003). The 'morality of things' is not simply about the constraints on some lines of action, it is also about the enabling and promotion of other types and patterns of behaviour. 
Secondly, the objects with which ordinary people engage demonstrate an increasing autonomy of action. The use of clockwork 'programmes' (in domestic washing machines as well as machine tools) has almost completely given way to more controllable, smaller and cheaper, computer based, controls. When combined with feedback sensors (thermostats, photo-electric cells) many of the objects we encounter display degrees of autonomy that would have been a fantasy a few decades ago. Such objects are better able to regulate and pattern our social behaviour.

Thirdly, the increased memory, motor and sensory capacity of objects that gives them greater autonomy, means that they are more able to substitute and 'delegate' for human beings and act as an interface between humans. ${ }^{14}$ Substitution may be of motor or communicative skills - the electric wheelchair substitutes for motor skills, the answer-phone for communicative skills. Both types may substitute for capacities in my body, or for capacities that could be supplied by another body (the wheelchair pusher, the telephone receptionist).

These changes in the materiality of everyday life have an impact on the civilizing process. It seems likely that the increase in the social complexity, autonomy and substitutability of our material world reduces the direct dependence we have on other human beings as our needs are met by material objects, with a consequent de-civilizing effect. But as material objects are interposed between us and other members of our society in networks and systems there is a lengthening of the chains of interdependence that connect us to more and more distant others. There is a civilizing effect as foresight, planning and self-control are required, both of ourselves as users of objects and by those who design, promote and constrain our use of them. There are ever longer and more complicated series of people who design, manufacture, distribute and sustain the material stuff of our everyday lives. But to the 
extent that we become less aware of the consequences of our actions on other humans, there is a decivilizing effect. ${ }^{15}$

The chains of interconnection that create the material environment spread across the world and involve people who share something of our material civilization and the sociality that accompanies it. The civilizing process operates as those along the chain increasingly recognize the effect on other humans of the particular material links that they are involved with. In her account of how techno-systems are enmeshed with everyday life - including those that use water to clean our possessions as well as us - Elizabeth Shove writes of the 'co-evolution... integration and co-ordination of suites of technologies and practices' (2003: 198). Just as our everyday lives adapt to standards of hygiene and cleanliness that are partly ideological and partly emergent from material possibilities, so those who deliver these systems are alert to the impact they have. Those who design, manufacture and deliver such systems do not do so from behind the closed doors of a factory but are increasingly aware of how their designs will be received. Herbert Blumer argued that fashion designers were best seen as the mediators of the extant culture in expressing a 'collective taste' rather than as innovators or originators (1969). In a similar way, Molotch (2003) undermines the idea that designers create material objects from their imagination, arguing that a range of sociocultural influences - including corporate interests, consumer studies, art and design history all feed into design.

\section{Conclusions}

I have argued that sociology needs to attend to the changes in material civilization that have shifted the agenda from Marx's concern with production, via the analysis of consumption to the way that objects affect individual social lives and at the same time, the life of our society. To interact with the material stuff that surrounds us is to unlock the human agency that has been 'congealed' within them through design and manufacture - this is what happens when you turn the key in a car's ignition or turn on a tap. The habitus of the late 
modern individual is more than ever constituted by material things that are appropriated through the senses and actions of the body.

The rapidity of change in material culture in late modernity means that it transforms far more quickly than languages can evolve, reversing the dominance of older age groups over younger, achieving its impact as much through its practical uses as through its capacity to signify social status. As our children teach us how to interact with the mobile phone, they are introducing their parents to a new range of objects that were just not there a few years ago, that demonstrate astonishing functional complexity and are made from materials specifically designed for their purpose - they can even act autonomously as an answer machine to substitute for us when we are not there. We have found uses for mobile phones within our everyday lives that could not have been precisely planned or intended by the most prescient engineer or entrepreneur. And yet as an object that has supremely symbolized the changing nature of material culture, it has also come to be a bearer of signs of social status and worthiness that has appealed to a wide variety of people.

What the changes in material civilization have produced is a society that we confront not so much directly through our interactions with its members or leaders but through our interaction with the material world that surrounds us. As we interact with the objects that we confront everyday in our lives we are also confronting the society that has designed and placed those objects around us. It is in these objects that the stable, consistent 'Other' of society is routinely manifest to us, providing the social background against which our warm human and sociable interactions take place. In the western industrialized world we have fashioned the embodied world we live in and in that sense we live in a material society. 


\section{Notes}

${ }^{1}$ I have in two books tried to address, admittedly rather unsystematically and far from adequately, some of the themes from this literature (Dant 1999, Dant 2005).

${ }^{2}$ The argument here may at times appear to be a 'soft' technological determinism or at least to have features of what Bruce Bimber (1994) calls a 'normative technological determinism' (for a range of contributions to this debate see Marx and Smith 1994). However, the intention is not to argue that either technology or materiality determine the state of civilization or society, only that the nature of civilization and the form of society cannot be properly understood without taking into account the impact of materiality on social relations. In the processual account of civilization developed below, no system, technological or social, determines any other but both have effects that bear on the nature of the other.

${ }^{3}$ Of course the capacity of chimps and other species to use tools has in recent decades diminished the species arrogance behind this presumption.

${ }^{4}$ It should be noted that Simmel does seem to have been interested in some of the impacts of a changing material civilization reflected in his scattered remarks about the impact of fashion, electric light, slot machines, typewriters and so on (1971; 1990).

5 'By producing their means of subsistence men are indirectly producing their actual material life' (Marx and Engels 1974: 42).

${ }^{6}$ In arguing that 'Marx de-emphasized consumption', Miller refers to this as a 'highly unsatisfactory section' (1987: 48).

${ }^{7}$ I am grateful to an anonymous referee for reminding that Braudel's is a particular and contested view of history and for indicating the relevance of Gourbet's work here.

${ }^{8}$ Domestic consumption in North America is around 400 litres per person per day, compared with 200 litres in Europe and 10-20 litres in many Sub-Saharan countries (Cosgrove and Risjberman 2000).

${ }^{9}$ Statement from Northumbrian Water, 'Hexham water supply', dated $12^{\text {th }}$ January 2005 posted at http://ww.nwl.co.uk, read on 12.01.05. 
10 'When water for washing and cooking has to be fetched from a well 10 minutes away, and water is subsequently piped into the house, then that represents an improvement in one's life' (Elias 1995: 5).

${ }^{11}$ Elias is interested in the creation or emergence of a technology only in passing; technization is related to but is not the same process as that usually studied by social studies of technology.

${ }^{12}$ This concept is of course also an extension of Bourdieu's (1986) account of the 'forms of capital'.

${ }^{13}$ Merleau-Ponty's impact on sociology and the social sciences in general is not easy to trace although O'Neil (1972; 2004 ) has long argued for his relevance and Crossley (2001) has recently used his work to explore a number of themes around the 'social body'.

${ }^{14}$ The term delegation here is used in Akrich and Latour's sense (1992).

${ }^{15}$ For example, as well as the civilizing effect of mobile phones connecting us to more people more easily they also lead to the de-civilizing effect of disturbing those around us on trains and in the theatre. But rules, advertisements and social approbation together with the use of 'silent' modes, texting and so on, lead to a further civilizing process. 


\section{Bibliography}

Akrich, Madeleine and Bruno Latour 1992 'A Summary of a Convenient Vocabulary for the Semiotics of Human and Nonhuman Assemblies.' in W. Bijker and J. Law (eds) Shaping Technology, Building Society: Studies in Sociotechnical Change, Cambridge, Mass, MIT Press.

Baudrillard, Jean 1993 [1976] Symbolic Exchange and Death, London: Sage.

Baudrillard, Jean 2000 The Vital Illusion, New York: Columbia University Press.

Bimber, Bruce 1994 'Three Faces of Technological Determinism' in L. Marx and M. R. Smith (eds) Does Technology Drive History? The Dilemma of Technological Determinism, Cambridge, Massachusetts: The MIT Press.

Bijker, W. E., Hughes, T. P., Pinch, T. J. (eds) 1987 The Social Construction of Technological Systems, Cambridge, MA: MIT Press.

Bijker, Wiebe and Law, John (eds) 1992 Shaping Technology/ Building Society: Studies in Sociotechnical Change, Cambridge, Massachusetts: MIT Press.

Blumer, Herbert 1969 'Fashion: From Class Differentiation to Social Selection', Sociological Quarterly 10: 275-91.

Bourdieu, Pierre 1984 Distinction: A Social Critique of the Judgement of Taste, London: Routledge.

Bourdieu, Pierre 1986 'The forms of capital' in J. Richardson (ed.) Handbook of Theory and Research for the Sociology of Education, New York: Greenwood Press.

Braudel, Fernand 1992 [1979] The Structures of Everyday Life: The Limits of the Possible, Berkeley, Los Angeles: University of California Press.

Burke, Peter 1990 The French Historical Revolution: The Annales School, 1929-89, Cambridge: Polity Press. 
Callon, Michel 1986 'The Sociology of an Actor-Network: The Case of the Electric Vehicle', in M. Callon, J. Law and A. Rip (eds) Mapping the Dynamics of Science and Technology: Sociology of Science in the Real World, Houndmills, Basingstoke: Macmillan.

Callon, M., Law, J. and Rip, A. (eds) 1986 Mapping the Dynamics of Science and Technology: Sociology of Science in the Real World, Houndmills, Basingstoke: Macmillan.

Campbell, Colin 1989 The Romantic Ethic and the Spirit of Modern Capitalism, Oxford: Blackwell.

Certeau, Michel de 1984 [1974] The Practice of Everyday Life, Berkeley: University of California Press.

Certeau, M. de, Giard, L. and Mayol, P. 1998 [1980] The Practice of Everyday Life, Volume 2: Living and Cooking, Minneapolis: Minnesota Press.

Cosgrove, William J. and Rijsberman, Frank R. 2000 World Water Vision: Making Water Everybody's Business, London: Earthscan Publications Ltd.

Costall, Alan 1995 'Socializing Affordances', Theory and Psychology 5(4): 467-81.

Crossley, Nick 2001 The Social Body: Habit, identity and desire, London: Sage.

Csikszentmihalyi, Mihaly \& Rochberg-Halton, Eugene 1981 The Meaning of Things:

Domestic symbols and the self, Cambridge: Cambridge University Press.

Dant, Tim 1999 Material Culture and the Social World: Values, Activities and Lifestyles, Buckingham: Open University Press.

Dant, Tim 2004 'The Driver-Car', Theory, Culture and Society - special issue on Automobility, 21 (4): 61-79.

Dant, Tim 2005 Materiality and Society, Maidenhead, Berks: Open University Press. 
Douglas, Mary \& Isherwood, Baron 1979 The World of Goods: Towards An Anthropology of consumption, London: Routledge.

Durkheim, Emile 1933 [1893] The Division of Labour in Society, New York: Free Press.

Elias, Norbert 1994 The Civilizing Process, Oxford: Blackwell.

Elias, Norbert 1995 'Technization and Civilization', Theory, Culture and Society 12 (3) 7-42.

Ellul, Jacques 1965 The Technological Society, London: Jonathan Cape.

Engels, Frederick 1971 [1845] The Condition Of The Working-Class In England in 1844, Oxford: Blackwell.

Gell, Alfred 1998 Art and Agency: An Anthropological Theory, Oxford: Clarendon Press.

Gourbet, Jean-Pierre 1986 The Conquest of Water: The Advent of Health in the Industrial Age, Princeton, New Jersey: Princeton University Press.

Heidegger, Martin 1977 The Question Concerning Technology and Other Essays, New York: Harper Row.

Hindmarsh, Jon and Heath, Christian 2003 'Transcending the Object in Embodied Interaction' in J. Coupland and R. Gwyn (eds) Discourse, the Body and Identity, Houndmills, Basingstoke: Palgrave Macmillan.

Hughes, Thomas P. 1983 Networks of Power: Electrification in Western Society 1880-1930, Baltimore: Johns Hopkins University Press.

Hutchby, lan 2001 'Technologies, Texts and Affordances' Sociology 35(2): 441-56.

Latour, Bruno 1988 'Mixing Humans and Nonhumans Together: The sociology of a doorcloser,' Social Problems 35(3): 298-310.

Latour, Bruno 1992 'Sociology of a Few Mundane Artifacts' in W. E. Bijker and J. Law (eds) Shaping Technology / Building Society: Studies in Sociotechnical change, Cambridge Mass. : MIT Press. 
Latour, Bruno 1999 Pandora's Hope: Essays on the Reality of Science Studies, Cambridge, Massachusetts: Harvard University Press.

Law, John and Callon, Michel 1992 'The Life and Death of an Aircraft: A Network Analysis of Technical Change' in W. Bijker and J. Law (eds) Shaping Technology/ Building Society: Studies in Sociotechnical Change, Cambridge, Massachusetts: MIT Press.

Lefebvre, Henri 1971 Everyday Life in the Modern World, London: Allen Lane, The Penguin Press.

McKendrick, N., Brewer, J. and Plumb, J.H. 1983 The Birth of a Consumer Society, London: Hutchinson.

MacKenzie, Donald and Wajcman, Judy (eds) 1985 The Social Shaping of Technology: A Reader, Milton Keynes: Open University Press.

McLuhan, Marshall 1994 [1964] Understanding Media: The Extensions of Man, Cambridge, Massachusetts: MIT Press.

Marx, Karl 1973 [1953] Grundrisse, Harmondsworth, Middlesex: Penguin Books.

Marx, Karl 1975 [1845] Early Writings, London: Penguin.

Marx, Karl 1976 [1867] Capital Volume One, London: Penguin Books.

Marx, Karl and Engels, Frederick 1974 [1965] The German Ideology: Students Edition, London: Lawrence and Wishart.

Marx, L. and Smith, M. R. (eds) 1994 Does Technology Drive History? The Dilemma of Technological Determinism, Cambridge, Massachusetts: The MIT Press.

Mauss, Marcel 1973 [1934] 'Techniques of the Body', Economy and Society 2(1): 70-88.

Merleau-Ponty, Maurice 1962 [1945] Phenomenology of Perception, London: Routledge.

Miller, Daniel 1987 Material Culture and Mass Consumption, Oxford: Blackwell. 
Molotch, Harvey 2003 Where Stuff Comes From: How Toaster, Toilets, Cars, Computers, and Many Other Things Come to Be As They Are, New York: Routledge.

Parlebas, Pierre 1999 'Les Tactique du corps', in M-P Julien and J-P Warnier (eds)

Approches de la Culture Matérielle, Paris: L'Harmattan.

Pinch, Trevor and Bijker, Wiebe 1987 'The Social Construction of Facts and Artifacts: Or How the Sociology of Science and the Sociology of Technology Might Benefit Each Other' in W. Bijker, T. Hughes and T. Pinch (eds) The Social Construction of Technological Systems: New Directions in the Sociology and History of Technology, Cambridge, Massachusetts: The MIT Press.

Roche, Daniel 2000 A History of Everyday Things, Cambridge: Cambridge University Press.

Shove, Elizabeth 2003 Comfort, Cleanliness and Convenience: The Social Organisation of Normality, Oxford: Berg.

Simmel, Georg 1950 The Sociology of Georg Simmel, edited by Kurt H. Wolff, Glencoe, III.: Free Press.

Simmel, Georg 1971 On Individuality and Social Forms: Selected Writings, edited by Donald N. Levine, Chicago: University of Chicago Press.

Slater, Don 1997 Consumer Culture and Modernity, Cambridge: Polity.

Veblen, Thorstein 1925 [1899] The Theory of the Leisure Class: An Economic Study of Institutions, London: George Allen \& Unwin.

Veblen, Thorstein 1964 [1914] The Instinct of Workmanship: And the State of the Industrial Arts, Augustus M. Kelly and the Sentry Press: New York.

Warnier, Jean-Pierre 2001 'A Praxaeological Approach to Subjectivation in a Material World', Journal of Material Culture 6(1): 5-24. 
Weber, Max 1978 [1921] Economy and Society, Edited by Guenther Roth and Claus Wittich, Berkeley, California: University of California Press. 